\title{
COMPARISON OF BUDBURST MODELS PREDICTIONS FOR KÉKFRANKOS
}

\author{
HLASZNY, E. ${ }^{1}-$ HAJDU, E. ${ }^{2}$ - BISZTRAY, GY. ${ }^{3}$ - LADÁNYI, M. ${ }^{1}{ }^{*}$ \\ ${ }^{1}$ Corvinus University of Budapest, Dept. of Mathematics and Informatics \\ 1118 Budapest, Villányi út 29-43., Hungary \\ (phone: +36-1-482-6261; fax: +36-1-466-9273) \\ ${ }^{2}$ Corvinus University of Budapest, Institute for Viticulture and Oenology, \\ Research Station of Kecskemét \\ 6000 Kecskemét, Katona Zsigmond. u. 5., Hungary \\ (phone: +36-76- 483-311; fax: +36-76-501-432) \\ ${ }^{3}$ Corvinus University of Budapest, Institute of Viticulture and Oenology, Dept. of Viticulture \\ 1118 Budapest, Villányi út 29-43., Hungary \\ (phone: +36-1-482-6283; fax: +36-1-466-4650) \\ *Corresponding authors \\ e-mail: marta.ladanyi@uni-corvinus.hu \\ gyorgy.bisztray@uni-corvinus.hu \\ (Received $11^{\text {th }}$ November 2011; accepted $5^{\text {th }}$ December 2011)
}

\begin{abstract}
Modelling the budburst dates are vital tools in viticulture, amongst others, for learning the response of the plants to climate change. We compared two budburst date models for Kékfrankos, the most important red variety of Hungary. The one is based on the accumulated effective heat sum with optimized starting date. The other one considers also the chilling effects and predicts the date of dormancy brake as well. The models were fitted and validated on phenological observations from 19772003 in a plain region of Central Hungary, Kecskemét. The optimization was made for the root mean square of the deviance between the predicted and the estimated dates measured in days. Keywords: Vitis vinifera L., Kékfrankos (Blaufränkisch), chilling effect, degree day, climate change
\end{abstract}

\section{Introduction}

As temperature is one of the main driving factors of plant development processes, phenology scheduling of Vitis vinifera $\mathrm{L}$. and its connection to climate change plays an important role in current studies (Penuelas and Filella, 2001; Walther et al., 2002; Khanduri et al., 2008). Budburst is an important ampelographic symptom. Every vine bud has one main bud and two side buds. The main buds break earlier as the side buds. In this work only budburst of main buds is studied.

Budburst is the beginning phenophase of grapevine vegetation period that depends on several climatic factors and genotype of the varieties. Budburst begins when some necessary (critical) biologically sufficient and necessary conditions are hold and contributes efficiently to the further development process of the plant. Thus, budburst can be a sensitive and well applicable indicator of clime change impact on the seasonal scheduling response of the plants which then have considerable ecologic and economic consequences.

When developing models one should decide which conditions should be considered as very important and which should be ignored in order to make the model as simple 
and as effective as possible. The suitability of the models is varying from varieties to varieties. Also the model parameters can be characteristic of varieties or sites.

Learning and forecasting the budburst dates are very important because we can deduce to the rate and probability of frost damage of the buds (Kramer, 1994a; Kramer et al., 1996). After budburst grape becomes sensible to chilly temperature, late spring frosts risk is high especially in May. The green sprouts can be injured even between $-0.5{ }^{\circ} \mathrm{C}$ and $-1{ }^{\circ} \mathrm{C}$. If chilly temperatures after the expected budburst are forecasted, plant protection can more successfully be managed. Some pests, for example mites (Eriophyes vitis Pag., Callepitrimerus vitis Nal., Tetranychus urticae L. ) and the fungus diseases (Uncinula necator (Schw.) Burr) spend the winter in the buds in great number and after the budburst they damage the young sprouts. Damages caused by these pests can be reduced if the budburst date is known and plant protection action is executed in the right time (Bognár, 1978).

There occurred some heat sum models even in the 1950s (Baggiolini, 1952) which were followed by intensive experimental and simulation work on the phenological responses of the plants on climatic effects (Hänninen, 1990, 1991, 1995, 1996; Hänninen et al., 1993). The late 1990s could bring significant improvement in modelling (Bonhomme, 2000; Chuine and Cour, 1999; Chuine et al., 1998, 2003). Chuine (2000) gives a pretty review and synthesis about the published models up to 2000 while a nice spatial and temporal comparison can be found in Cortázar-Atauri et al. (2009). In Hungary such kind of models are not yet in practice.

Several phenology models for the estimation of budburst dates are based on the wide accepted concept that budburst date of Vitis vinifera L. is mainly determined by the effective heat sum after the chilling effect in dormancy (Carbonneau et al., 1992; Jones, 2003; Jones et al., 2005).

According to this, dormancy can be separated in two periods: the first one is defined as the period when buds are dormant due to physiological conditions (endodormancy) and the second is when buds remain dormant just because of unfavourable environmental conditions (ecodormancy) (Lang et al., 1987; Cesaraccio et al., 2004).

In the literature there are several budburst models for different varieties and regions. The most of them agree in the concept of heat accumulation, i.e. the daily average temperature above a base temperature (mostly above $10^{\circ} \mathrm{C}$ ) is summed from a starting date. Budburst occurs when a critical threshold is reached (Moncur et al., 1989). This model can be regarded as the simplest model of budburst prediction with three parameters to calibrate: the starting date, the base temperature and the critical value to reach.

The simplest model can be refined from several aspects. Setting out from the average daily temperatures accumulation can be made as a linear or other (e.g. logarithmic) function (Oliveira 1998; Riou, 1994). The scale of accumulation can be chosen as daily or hourly steps (Cortázar-Atauri et al., 2005). In case hourly steps are applied detailed (observed or estimated) data on sunrise and sunset are needed. Then we can decide whether triangle, exponential or sine type approximation of the daily heat distribution is used (Spano et al., 2002). In several cases, however, highly sophisticated models do not fill the expected accuracy because of the great number of estimated parameters (Riou, 1994; Cortázar-Atauri et al., 2009).

The starting date of accumulation is of great importance, though the most widely used date is the $1^{\text {st }}$ of January (Riou, 1994; Bindi et al., 1997 a,b). However, setting the starting date more precisely with optimization has a great advantage. 
Chuine and Cour (1999) have investigated four temperate-zone tree species. Their results show that the more chilling units are cumulated in endodormancy, the earlier the ecodormancy starts and the less effective heat accumulation is needed for budburst. Several other researchers agree this (Nienstaedt, 1966; Farmer, 1968; Nelson and Lavender; 1979; Heide, 1993; Hänninen and Backman, 1994; Myking and Heide, 1995). Therefore the relationship between the length of the chilling period and the length of the forcing period required for budburst is important in predicting budburst timing.

\section{Materials and methods}

Our study was focused on Kékfrankos red wine variety. Its origin is uncertain, but according to Németh (1967) it belongs to the Vitis vinifera L. convarietas orientalis subconvarietas caspica. It spread mostly in Hungary. It can be found in most of the red wine-growing areas; moreover, Kékfrankos is a relevant variety in the most regions. It is the first amongst the regional hierarchy of the red wine varieties. Because of many valuable properties, Kékfrankos remains as a promising variety even in the future (Bényei and Lörincz, 2005). It is winter hardy until $-19^{\circ} \mathrm{C}$.

The examined vineyard is in high cordon training system with Sylvoz pruning (Hajdu and Saskői, 2009). The phenology data we used came from the Research Institute for Viticulture and Oenology, Kecskemét. There were collected 20-years data between 1977 and 2003 with missing values in years 1980, 1987 and from 1993 to 1997. The experimental station is situated in South Great Hungarian Plain Region in Kecskemét, in the part of the Kunsági wine region. The observed vineyard is situated in north of Kecskemét towards Nagykörös. In this region the soil is sandy with very low (below 1\%) humus content (Pernesz, 2004). The ground-water is high $(2-5 \mathrm{~m})$ in general, but nowadays its diminution was experienced (Bényei et al., 1999). Its climate is continental. Drought summers, frosty cold winters, early frosts in autumn and late frosts in spring are very frequent in this region. (For example there is winter frost even with $-21{ }^{\circ} \mathrm{C}$ detected at the Great Hungarian Plain in every third year as an average.) On scorching hot days sunburn and heat shock events of vine are common. The yearly average precipitation is $550 \mathrm{~mm}$ (1962-2004). It can usually be detectable about 100 $\mathrm{mm}$ yearly precipitation lack. Amongst the wine-growing areas the growing security is the worst here (Kozma, 1991).

Meteorological data with daily average temperatures are from the Hungarian Meteorological Service. For climate change impact study we applied RegCM 3.1 which was downscaled at Eötvös Loránd University, Department of Meteorology for A1B scenario (Bartholy et al., 2007, 2009, 2010; Torma et al., 2008). We considered three different time scales: 1961-1990 as reference period, 2021-2050 and 2071-2100 as prediction time intervals.

\section{The Degree Days Model}

We tried to find a relatively simple model that can estimate the budburst date of Kékfrankos from Kecskemét, Hungary in the time period 1977-2003 as accurate as possible.

The average daily temperatures above the base temperature were accumulated from a starting date up to the observed budburst in each year. Gladstones (2000) proposed that also an upper base temperature should be considered because the plant is unable to 
utilise the heat above a critical limit. For that purpose we also applied the upper base temperature as follows:

$$
G D D_{j}=\sum_{i=\text { start }}^{\text {budburst }} \max \left[\left(\min \left(T_{\text {aver_i,j }}, T_{\text {upperbase }}\right)-T_{\text {lowerbase }}\right) ; 0\right]
$$

where:

$T_{\text {aver }-i, j}$ denotes the daily average temperature in a year $j$ and on a day $i$,

$T_{\text {lowerbase }}$ and $T_{\text {upperbase }}$ are the base temperature parameters.

The model indicates the budburst date when a critical sum denoted by $G D D_{d_{-} \text {crit }}$ is reached.

\section{The Unified Model}

The Unified Model is more sophisticated than Degree Days Model as it takes the information of the chilling effect into account (Chuine, 2000). In addition to breaking dormancy, chilling temperatures have an accelerating effect on bud growth. The more chilling effect indicates less degree days that are necessary to reach the budburst (Nelson and Lavender, 1979; Cannell and Smith, 1983; Murray et al., 1989; Kramer, 1994b; Chuine et al., 1999). Thus we distinguish the chilling $(\mathrm{CH})$ and the forcing $(F)$ effects and define them dimensionless as:

$$
\begin{gathered}
C H_{j}=\sum_{1 . \text { Sept. }}^{t_{j}} \frac{1}{1+\exp \left(a\left(T_{\text {aver_i,j }}-T_{\text {base }, C H}\right)^{2}+b\left(T_{\text {aver_i,j }}-T_{\text {base }, C H}\right)\right)} \\
F_{j}=\sum_{t_{j}}^{\text {budbreak }} \frac{1}{1+\exp \left(c\left(T_{\text {aver_i,j }}-T_{\text {base }, F}\right)\right)}
\end{gathered}
$$

where:

$a, b, c$ are empirical parameters,

$T_{\text {aver }-i, j}$ denotes the daily average temperature in a year $j$ and on a day $i$,

$T_{\text {base }, \mathrm{CH}}$ and $T_{\text {base }, \mathrm{F}}$ are base temperature parameters regarding the chilling and forcing effects, respectively,

$t_{j} \quad$ is the point of time when the required chilling effect $\left(\mathrm{CH}_{c r i t}\right)$ is fulfilled in a year $j$.

At this point the model indicates the end of the endodormancy and the heat accumulation of $F_{j}$ sets off. Budburst date is highlighted by the model when the required effective heat sum $G D D_{u_{-} \text {crit }}$ is reached.

The range of the chilling and forcing functions is the interval ]0,1[. The shape of the chilling effect function is a curve with a peak at the point where the chilling effect is optimal and limits of zero as tending to positive or negative infinity; while the forcing function has a sigmoid type curve (Fig. 1). 

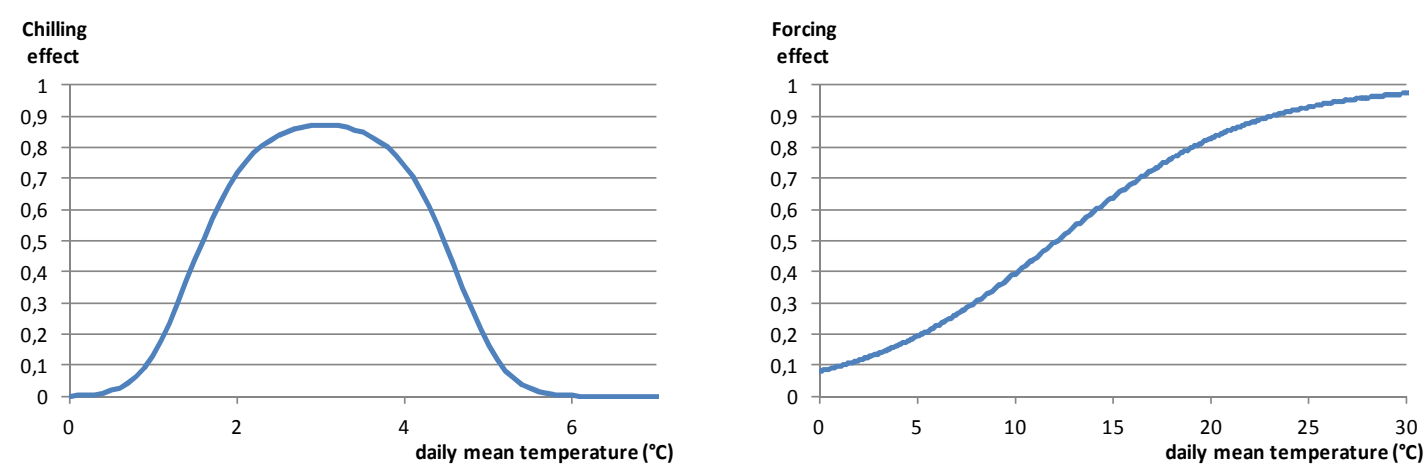

Figure 1. Chilling and forcing effect characteristic curves

In Fig. 2 we can see the chilling and forcing effect accumulation process in a randomly chosen year. The horizontal lines are for the chilling $\left(\mathrm{CH}_{c r i t}\right)$ and forcing ( $\left.G D D_{u_{-} c r i t}\right)$ accumulation criteria. The vertical lines are for the model predicted date of dormancy break and date of budburst, respectively.

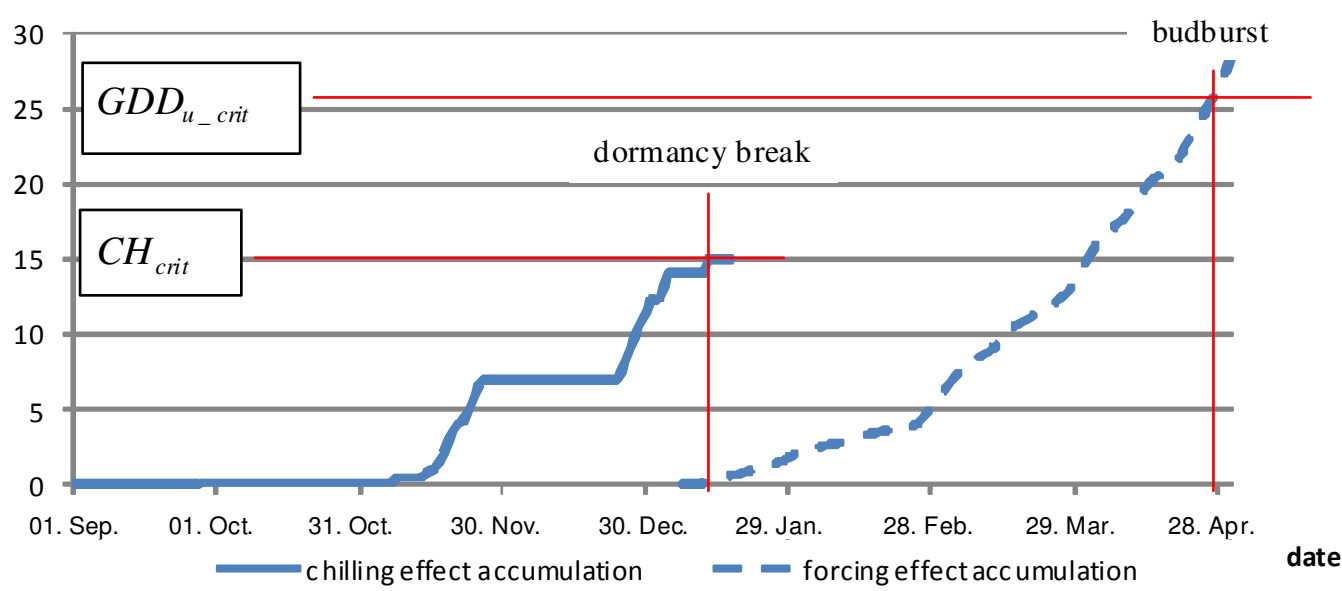

Figure 2. Chilling and forcing effect accumulation during the dormancy and after the dormancy break in an arbitrary chosen year. At the point of time when the required chilling effect is fulfilled, the model indicates the end of the endodormancy and heat accumulation sets off. Budburst date is highlighted by the model when the required effective heat sum is reached.

\section{Fitting and validation procedure}

The available dataset was split into two parts: data of 10 years were used for calibration while the remaining ones for validation.

The root mean square error (RMSE) was defined as the root of the average sum of the squares of the differences between the observed $\left(B B_{o b s}\right)$ and estimated budburst dates $B B_{\text {pred }}$ measured by days:

$$
R M S E=\sqrt{\frac{1}{N} \sum_{j}\left(B B_{o b s}-B B_{\text {pred }}\right)^{2}}
$$

where $N$ denotes the number of years. In case of Degree Days Model RMSE was minimized while both the base temperatures $T_{\text {lowerbase }}$ and $T_{\text {upperbase }}$ and the starting 
date together with the critical value $G D D_{d_{-} \text {crit }}$ were varied. For optimization we used Palisade's Risk Evolver that is based on innovative genetic algorithm (GA technology), a stochastic directed searching technique with several thousands of iteration. This method does not get stuck at local solutions, but instead looks at the entire range of possible solutions which enables us to find the global optimal solution instead of a local extreme value (Weise, 2009).

For Unified Model again the root mean square error was minimized with innovative genetic algorithm while seven parameters namely $a, b, c, T_{b a s e, C H}$ and $T_{b a s e, F}$ as well as $C H_{c r i t}$ and $G D D_{u_{-} c r i t}$ were varied in the parameter space.

\section{Regional climate model prediction survey}

The calibrated and validated model was run with input coming from the regional climate model RegCM 3.1 for three time intervals: 1961-1990 as reference period, 2021-2050 and 2071-2100 for prediction. We calculated the distributions of the budburst date predictions for these three time intervals and compared them with oneway ANOVA. Variance homogeneity was checked with Levene test. Post Hoc test was made by Tukey test. The error terms and the distributions were fitted to normal distribution with Shapiro-Wilk test using @ Risk of Palisade. Finally we compared the fitted distributions.

\section{Results and discussion}

The optimized parameters of the Degree Days Model and the ones of the Unified Model can be found in Table 1. The error terms are normally distributed $(\mathrm{p}=0.08$; $\mathrm{p}=0.42)$.

Table 1. The optimized parameters of Degree Days Model and the ones of the Unified Model

\begin{tabular}{cc|cc|cc}
\hline \multicolumn{2}{c|}{ Degree Days Model } & \multicolumn{5}{c}{ Unified Model } \\
Chilling effect & \multicolumn{2}{c}{ Forcing effect } \\
\hline starting Julian day (day) & 47 & $\mathrm{a}$ & 1 & $\mathrm{c}$ & -0.20 \\
$T_{\text {lowerbase }}\left({ }^{\circ} \mathrm{C}\right)$ & 4.54 & $\mathrm{~b}$ & 2.65 & & \\
$T_{\text {upperbase }}\left({ }^{\circ} \mathrm{C}\right)$ & 18.4 & $T_{\text {base }, C H}$ & 4.58 & $T_{\text {base }, F}\left({ }^{\circ} \mathrm{C}\right)$ & 12.11 \\
$G D D_{d_{-} \text {crit }}\left({ }^{\circ} \mathrm{C}\right)$ & 260 & $C H_{\text {crit }}$ & 14 & $G D D_{u_{-} \text {crit }}\left({ }^{\circ} \mathrm{C}\right)$ & 25 \\
\hline
\end{tabular}

We judged the Unified Model as a better tool for estimation as the RMSEs, the mean and the absolute error values are considerably smaller in case of this model (Fig. 3). The explained variances $\left(\mathrm{R}^{2}\right)$ are significant for both models $(\mathrm{p}<0.05)$, the ones of Unified Models are higher. Moreover, for the model validation any of the four values (RMSE, mean error, absolute error, $\mathrm{R}^{2}$ ) worse significantly compared to the calibration results. 

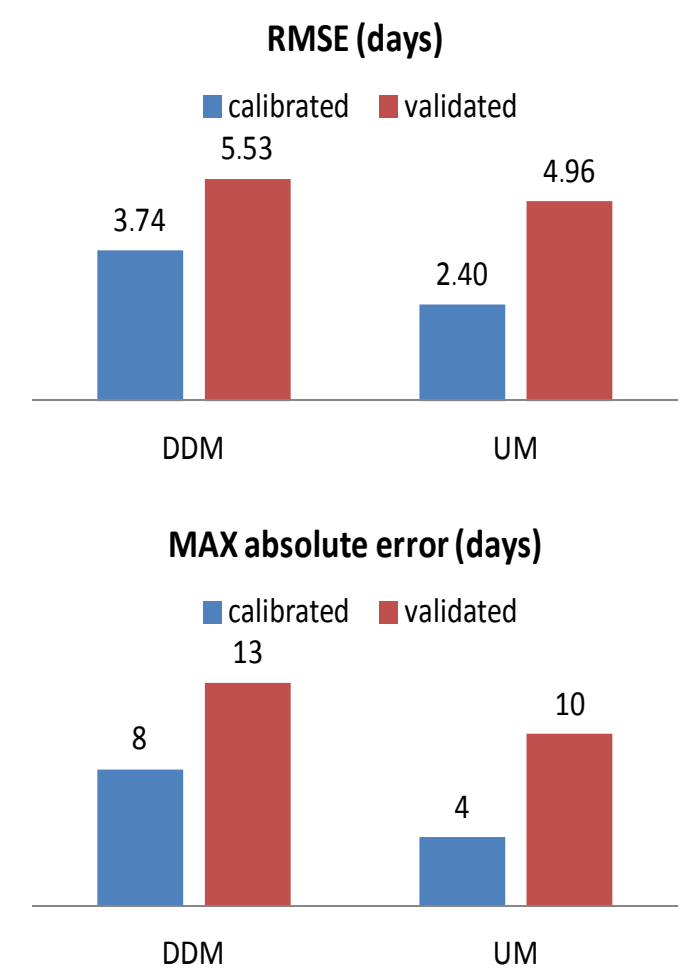

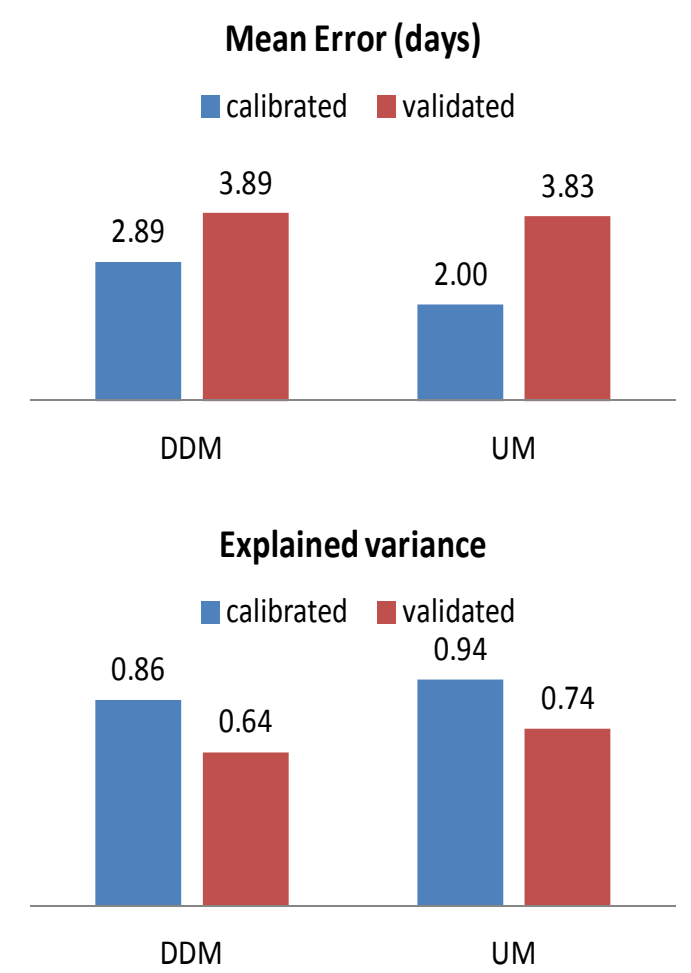

Figure 3. Root mean square errors (RMSE, days), mean errors (days), maximal absolute values of the errors (days) and the explained variances $\left(R^{2}\right)$ of the Degree Days Model (DDM) and Unified Model (UM) for the calibrated and the validated data set

The budburst predictions of the Unified Model for the future are significantly different from the ones of the reference period $(\mathrm{p}<0.01$, Levene test $\mathrm{p}=0.87$; ShapiroWilk normality test for the residuals $\mathrm{p}=0.09$ ). However, the future predictions do not differ from each other significantly, Tukey $\mathrm{p}=0.94$ ). The budburst distributions of all the three time periods can be fitted to normal distribution with parameters of Table 2. ( $p>0.2)$. With time it is expected that the distributions shift to the left for earlier mean budburst date at a rate of about ten days and have increasing estimated variances and thus increasing coefficients of variation (Table 2, Fig. 4).

Table 2. Means of the budburst dates predicted by the Unified Model, their variances and coefficients of variances referring to 1961-90 as reference period as well as to the time intervals 2021-2050, 2071-2100 based on the daily outputs of regional climate model RegCM3.1

\begin{tabular}{c|c|c|c}
\hline Time interval & Mean (J. day) & Standard deviation & CV \\
\hline $1961-1990$ & 113.26 & 10.83 & 0.096 \\
$2021-2050$ & 104.67 & 11.27 & 0.11 \\
$2071-2100$ & 103.67 & 12.21 & 0.12 \\
\hline
\end{tabular}



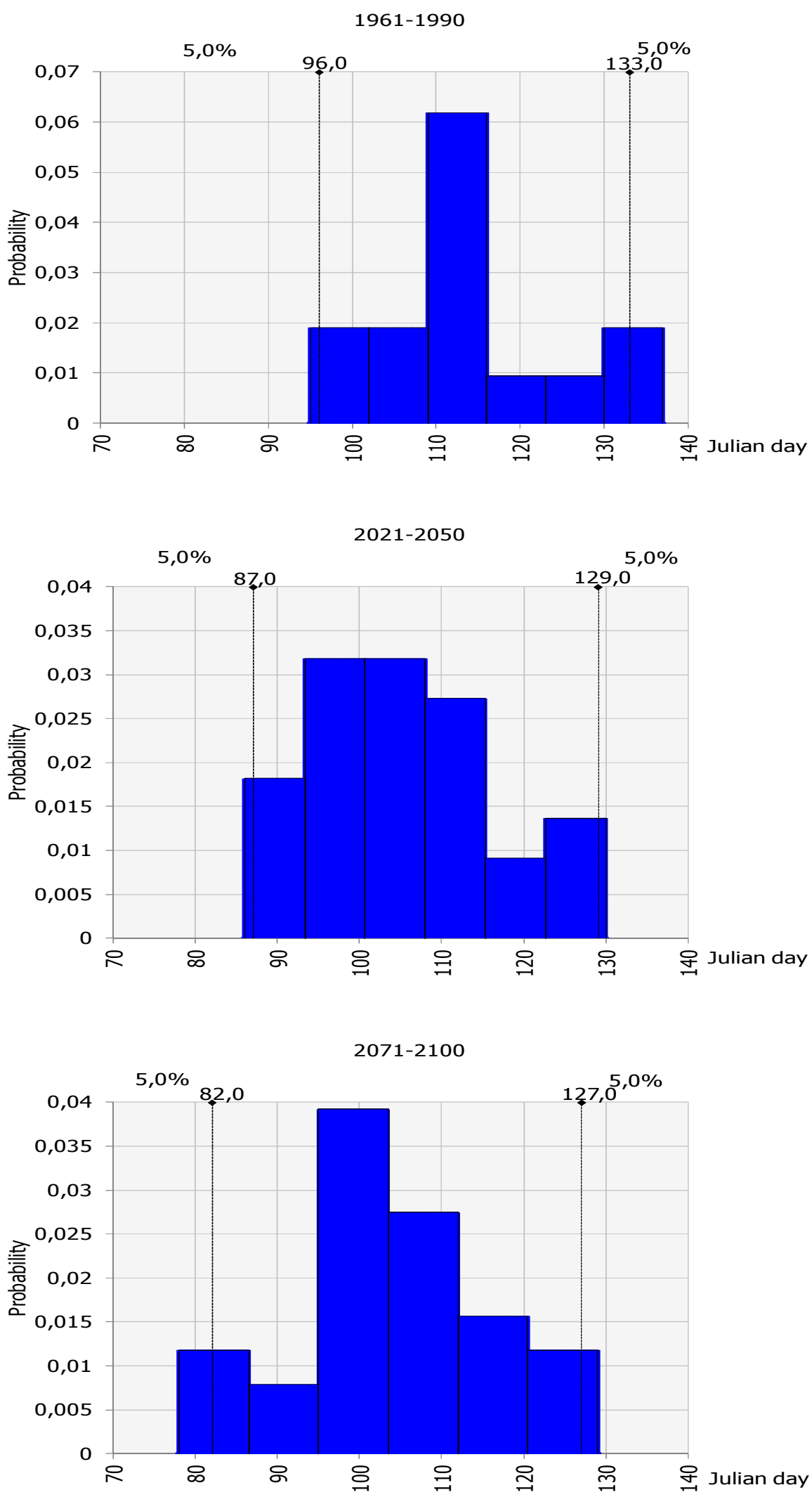

Figure 4. Budburst date relative frequency histograms predicted by the regional climate model RegCM 3.1 for time intervals 1961-1990, 2021-2050 and 2071-2100 with their $90 \%$ confidence interval highlighted 
In Fig. 5 we can compare the normal distributions that can be fitted to the relative frequency histograms with the mean and standard deviation parameters predicted by the Unified Model run with the regional climate model RegCM 3.1.

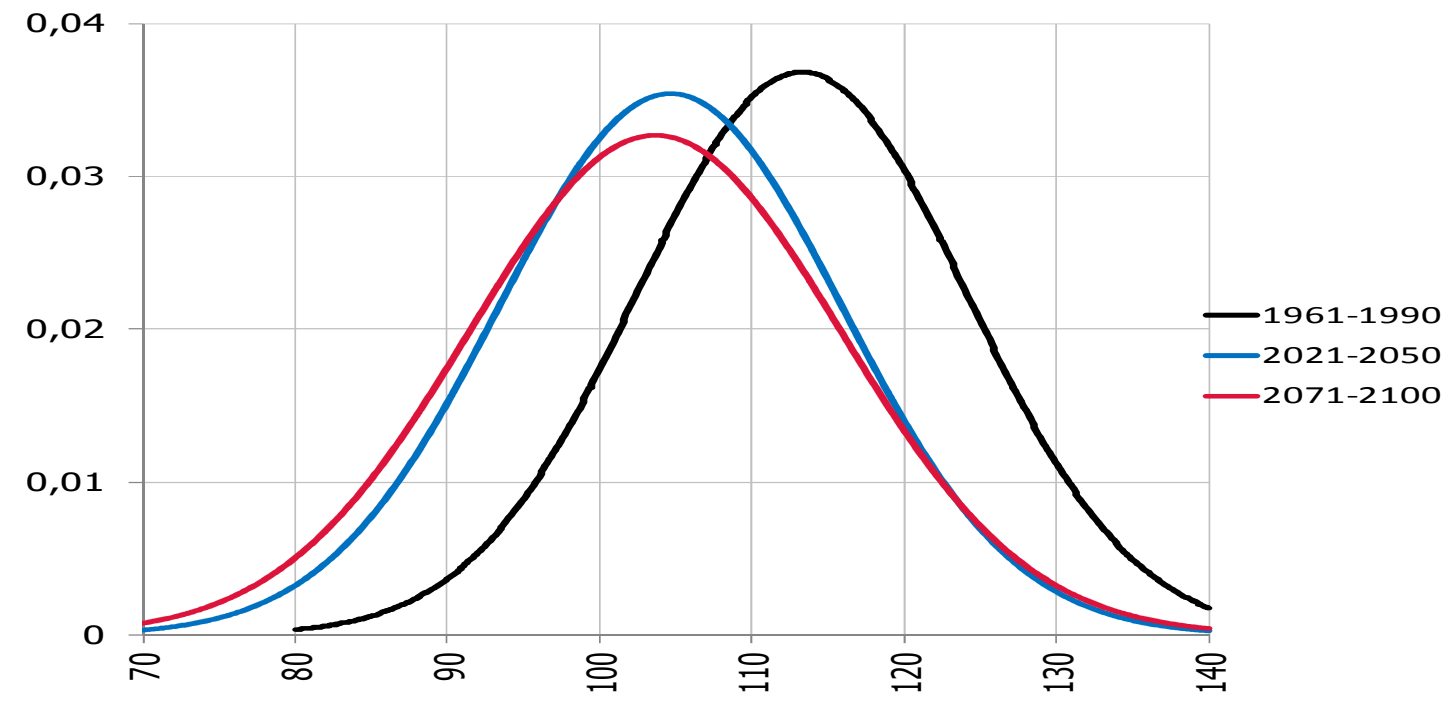

Figure 5. Fitted normal distribution curves for the budburst dates predicted by the regional climate model RegCM 3.1 for time intervals 1961-1990, 2021-2050 and 2071-2100

The predicted phenological shift of budburst of about ten days (2021-2050, 20712100) compared to the reference period 1961-90 can have considerable biological consequences. This result, on one hand, verifies the necessity and usefulness of modelling budburst dates and, on the other hand, motivates the researchers to find more and more accurate models which can predict and warn future tendencies. We stress the need of further and continuous improvement of the models because climate change impact itself can change with time if delayed feedback is also considered. Moreover, the impact of climate change is manifested not only in tendentious changes but also in the extreme events with increasing frequencies and seriousness. This latter impact, however, is still very poorly modelled. Nevertheless, the impact of tendentious changes can be overwritten by some kinds of extreme event impact such as warm winters, spring frosts etc. Therefore we emphasize that budburst models based on chilling effect calculations can be applied mostly in regions where chilling requirements are usually largely fulfilled which is the case of Hungary now but can be changed while climate character varies.

Though our model was calibrated specially for one of the most important Hungarian red grape variety, Kékfrankos (Blaufränkisch), we can successfully apply it also for other varieties while keeping in mind that the calibrated parameters can be very sensitive to varieties and sites.

The consequences of the earlier budburst events forecasted by the phenology models together with the regional climate models can be both beneficial and also detrimental. Earlier budburst with similar or lightly warming spring temperature distribution involves the increasing risk of spring frost. The most serious spring frost events occur usually after an early budburst followed by an intensive temperature drop. Though Kékfrankos is frost resistant pretty well, young sprouts can be injured after budburst 
caused by even a moderately serious frost. Therefore, beyond the model based prediction of budburst dates, we emphasize that the forecast of the probability of spring frost events together with accurate calculations of frost risk damages are also the sorely demanded.

Acknowledgements. This research was supported by TÁMOP-4.2.1/B-09/1/KMR-2010-0005 project.

\section{REFERENCES}

[1] Baggiolini, M. (1952): Les stades repères dans le développement annuel de la vigne et leur utilisation pratique. - Rev. Romande Agric. Vitic. Arbor. (8): 4-6.

[2] Bartholy, J., Pongrácz, R., Barcza, Z., Haszpra, L., Gelybó, Gy., Kern, A., Hidy, D., Torma, Cs., Hunyady A., Kardos, P. (2007): A klímaváltozás regionális hatásai: a jelenlegi állapot és a várható tendenciák. - Földrajzi Közlemények. CXXXI. (LV.) kötet, 4. szám, pp. 257-269.

[3] Bartholy, J., Pongrácz, R., Torma, Cs. (2010): A Kárpát-medencében 2021-50-re várható regionális éghajlatváltozás RegCM-szimulációk alapján. - "KLÍMA-21” Füzetek, 60: 3-13.

[4] Bartholy, J., Pongrácz, R., Torma, Cs., Pieczka, I., Kardos, P. and Hunyady, A. (2009): Analysis of regional climate change modelling experiments for the Carpathian basin. International Journal of Global Warming 1(1-2-3.): 238-252.

[5] Bényei, F., Lőrincz, A. (2005): Borszőlőfajták, csemegeszőlö-fajták és alanyok. Mezőgazda Kiadó, Budapest

[6] Bényei, F., Lőrincz, A., Sz. Nagy, L. (1999): Szőlőtermesztés. - Mezőgazda Kiadó, Budapest

[7] Bindi, M., Miglietta, F., Gozzini, B., Orlandini, S., Seghi, L. (1997a): A simple model for simulation of growth and development in grapevine (Vitis vinifera L.). I. Model description. - Vitis 36(2): 67-71.

[8] Bindi, M., Miglietta, F., Gozzini, B., Orlandini, S., Seghi, L. (1997b): A simple model for simulation of growth and development in grapevine (Vitis vinifera L.). II. Model validation. - Vitis 36(2): 73-76.

[9] Bognár, S. (1978): Kertészeti növényvédelem. - Mezőgazdasági Kiadó, Budapest

[10] Bonhomme, R. (2000): Bases and limits to using "degree-day" units. - Eur. J. Agron. (13): 1-10.

[11] Cannell, M. G. R., Smith, R. I. (1983): Thermal time, chill days and prediction of budburst in Picea sitchensis. - J. Appl. Ecol. (20): 951-963.

[12] Carbonneau, A., Riou, C., Guyon, D., Riom, J., Schneider, C. (1992): Agrométéorologie de la vigne en France. - EUR-OP, Luxembourg

[13] Cesaraccio, C, Spano, D., Snyder, R.L., Duce, P. (2004): Chilling and forcing model to predict bud-burst of crop and forest species. - Agric. For Meteorol. (126): 1-13.

[14] Chuine, I. (2000): A unified model for budburst of trees. - J. Theor. Biol. (207): 337-347.

[15] Chuine, I., Cour, P. (1999): Climatic determinants of budburst seasonality of temperatezone trees. - The New Phytol. (143): 339-349.

[16] Chuine, I., Cour, P., Rousseau, D.D. (1998): Fitting models predicting dates of flowering of temperate-zone trees using simulated annealing. - Plant, Cell Environ. (21): 455-466.

[17] Chuine, I., Cour, P., Rousseau, D.D. (1999): Selecting models to predict the timing of flowering of temperate trees: implications for tree phenology modelling. - Plant, Cell Environ. (22): 1-13.

[18] Chuine, I., Kramer, K., Hänninen, H. (2003): Plant development models. - In: Schwartz, M.D. (ed) Phenology: an integrative environmental science. Kluwer, Milwaukee, pp. 217-235.

[19] Cortázar-Atauri, G.I., Brisson, N., Seguin, B., Gaudillere J.P., Baculat, B. (2005): Simulation of budbreak date for vine. The BRIN model. Some applications in climate 
change study. - In: Proceedings of XIV International GESCO Viticulture Congress, Geisenheim, Germany, 23-27 August, 2005, pp 485-490.

[20] Cortázar-Atauri, G.I., Brisson, N., Gaudillere, J.P. (2009): Performance of several models for predicting budburst date of grapevine (Vitis vinifera L.) - Int. J. Biometeorol DOI 10.1007/s00484-009-0217-4.

[21] Farmer, R.E. (1968): Sweetgum dormancy release : effects of chilling, photoperiod, and genotype. - Physiologia Plantarum (21): 1241-1248.

[22] Gladstones, J. (2000): Past and future climatic indices for viticulture. - Proc. 5th Intl. Symp. Cool Climate Vitic. Oenol., Melbourne, Australia. p. 10.

[23] Hänninen, H. (1990): Modelling bud dormancy release in trees from cool and temperate regions. - Acta For. Fenn. (213): 1-47.

[24] Hänninen, H. (1991): Does climatic warming increase the risk of frost damage in northern trees? - Plant, Cell Environ. (14): 449-454.

[25] Hänninen, H. (1995): Effect of climatic change on trees from cool and temperate regions: an ecophysiological approach to modelling of bud burst phenology. - Can. J. Bot. (73):183-199.

[26] Hänninen, H. (1996): Effects of climatic warming on northern trees: testing the frost damage hypothesis with meteorological data from provenance transfer experiments. Scan. J. For. Res. (11): 17-25.

[27] Hänninen, H., Backman, R. (1994): Rest break in Norway spruce seedlings: test of a dynamic temperature response hypothesis. - Canadian Journal of Forest Research (24): 558-563.

[28] Hänninen, H., Kellomag Ki, S., Laitinen, K., Pajari, B., Repo, T. (1993): Effect of increased winter temperature on the onset of height growth of Scots pine: a "led test of a phenological model. - Silva Fennica (27): 251-257.

[29] Heide, O.M. (1993): Daylength and thermal time responses of budburst during dormancy release in some northern deciduous trees. - Physiologia Plantarum (88): 531-540.

[30] Hajdu, E., Saskői, B.-né (2009): Abiotikus stresszhatások a szőlö életterében Agroinform Kiadó, Budapest, p. 222.

[31] Jones, G.V. (2003): Winegrape phenology. - In: Schwartz, M.D. (ed) Phenology: an integrative environmental science. Kluwer, Milwaukee, pp. 523-540.

[32] Jones, G.V, Duchene, E., Tomasi, D., Yuste, J., Braslavksa, O., Schultz, H., Martinez, C., Boso, S., Langellier, F., Perruchot, C., Guimberteau, G. (2005): Changes in European winegrape phenology and relationships with climate. - In: Proceedings of XIV International GESCO Viticulture Congress, Geisenheim, Germany, 23-27 August, 2005, pp. 55-62.

[33] Khanduri, V.P., Sharma, C.C.M., Singh, C.S.P. (2008): The effects of climate change on plant phenology. - Environmentalist (28):143-147.

[34] Kozma, P. (1991): A szőlő és termesztése I. A szőlőtermesztés történeti, biológiai és ökológiai alapjai. - Akadémiai Kiadó, Budapest

[35] Kramer, K. (1994a): A modelling analysis of the effects of climatic warming on the probability of spring frost damage to tree species in The Netherlands and Germany. Plant, Cell Environ. (17): 367-377.

[36] Kramer, K. (1994b): Selecting a model to predict the onset of growth of Fagus sylvatica. - J. Appl. Ecol. (31): 172-181.

[37] Kramer, K., Friend, A., Leinonen, I. (1996): Modelling comparison to evaluate the importance of phenology and spring frost damage for the effects of climate change on growth of mixed temperate-zone deciduous forests. - Clim. Res. (7): 31-41.

[38] Lang, G.A., Early, J.D, Martin, G.C., Darnell, R.L. (1987): Endo-, para-, and ecodormancy: physiological terminology and classification for dormancy research. HortScience 22(3): 371-377. 
[39] Moncur, M.W., Rattigan, K., Mackenzie, D.H., McIntyre, G.N. (1989): Base temperatures for budbreak and leaf appearance of grapevines. - Am. J. Enol. Vitic. 40(1): 21-26.

[40] Murray, M. B., Cannell, M. G. R., Smith, R. I. (1989): Date of budburst of fifteen tree species in Britain following climatic warming. - J. Appl. Ecol. (26): 693-700.

[41] Myking, T, Heide, O.M. (1995): Dormancy release and chilling requirements of buds of latitudinal ecotypes of Betula pendula and B. pubescens. - Tree Physiology (15):697-704.

[42] Nelson, E.A, Lavender, D.P. (1979): The chilling requirement of western hemlock seedlings. - Forest Science 25: 485-490.

[43] Németh, M. (1967): Ampelográfiai album I. (Termesztett borszőlőfajták 1.). Mezőgazdasági Kiadó, Budapest

[44] Nienstaedt, H. (1966): Dormancy and dormancy release in white Spruce. - Forest Science (12): 374-384.

[45] Oliveira, M. (1998) Calculation of budbreak and flowering base temperatures for Vitis vinifera cv. Touriga Francesa in the Douro Region of Portugal. - Am. J. Enol. Vitic. 49(1):74-78.

[46] Penuelas J., Filella, I. (2001): Phenology: responses to a warming world. - Science (294): 793-794.

[47] Pernesz, Gy. (2004): New resistant table grape cultivars bred in Hungary. - Proceedings of the First International Symposium on Grapewine Growing, Commerce and Research, Acta Horticulturae (652): 321.

[48] Riou, C. (1994): The effect of climate on grape ripening: application to the zoning of sugar content in the European community. - CECACEE- CECA, Luxembourg.

[49] Spano, D, Cesaraccio, C., Duce, P. and Snyder, R.L. (2002): An improved model for estimating degree days. - ISHS Acta Horticulturae 584: VI International Symposium on Computer Modelling in Fruit Research and Orchard Management.

[50] Torma, Cs., Bartholy, J., Pongrácz, R., Barcza, Z., Coppola, E., Giorgi, F. (2008): Adaptation and validation of the RegCM3 climate model for the Carpathian Basin. Időjárás 112(3-4): 233-247.

[51] Walther, G.R., Post, E., Convey, P., Menzel, A., Parmesan, C., Beebee, T.J.C., Fromentin, J.M., Guldberg, O.H., Bairlein, F. (2002): Ecological responses to recent climate change. - Nature (416):389-395.

[52] Weise, T. (2009): Global Optimization Algorithms - Theory and Application http://www.it-weise.de/projects/book.pdf. 